\title{
Persistência de úraco e poliartrite séptica em equino neonato
}

Maísa Alves Batista de Souza, Igor Mariz Dantas, Ruy Brayner de Oliveira Filho, Karla Campos Malta, Roberta Máira Pereira, Suedney Lima Silva, Isabella de Oliveira Barros

Universidade Federal da Paraíba (UFPB), Areia, PB, Brasil

*Autor correspondente

e-mail: doutorabella@hotmail.com

\section{Resumo}

A artrite séptica pode ser definida como uma manifestação inflamatória de uma articulação. É uma enfermidade que acomete tanto potros quanto equinos adultos, não tendo predisposição. É a complicação mais grave constatada nas articulações dos equinos. A artrite séptica em potros está comumente envolvida a um sítio primário de sepse existente em algum local do organismo ou em parte do corpo, causando bacteremia. 0 presente relato teve como objetivo descrever um caso de poliartrite séptica em potro da raça Quarto de Milha, atendido no Hospital Veterinário da UFPB. 0 animal tinha 22 dias de vida e há cerca de 10 dias apresentara secreção ocular bilateral com ulceração e também um aumento de volume nas articulações társicas, bilateral. No umbigo havia secreção purulenta e eliminava urina. No ultrassom da região umbilical, visualizou-se aumento da área de ecogenicidade, e no ultrassom feito da região társica, líquido hiperecóico com pontos de fibrina. Sistemicamente, o tratamento antimicrobiano constituído foi à base de penicilina ( $40.000 \mathrm{UI} / \mathrm{kg}$ ) e gentamicina ( $3 \mathrm{mg} / \mathrm{kg}$ ). Para o controle da dor foi administrado meloxicam $(0,5 \mathrm{mg} / \mathrm{kg}$ ), e para febre, dipirona na dose de 25 $\mathrm{mg} / \mathrm{kg}$. Foi realizada uma artrocentese devido à dificuldade de eliminar a secreção purulenta. Foi feita também a lavagem articular com amicacina (500mg/animal) diluída em $250 \mathrm{ml}$ de solução fisiológica, associada a $5 \mathrm{ml}$ de dimetilsulfóxido, e bandagem no local. Com o tratamento, executado por uma semana, houve uma redução da infeção articular, porém esta não foi sanada. 0 tratamento para persistência de úraco consistiu na intervenção cirúrgica através da laqueadura do úraco junto à vesícula urinária. 0 animal permaneceu internado durante duas semanas e posteriormente recebeu alta. $\mathrm{O}$ animal foi encaminhado para a propriedade, contudo, por falta de manejo, ficou sem alimentação, vindo a óbito 24 horas após chegar na propriedade, segundo relato do proprietário. Desta forma, é de grande importância adotar como prevenção um manejo ideal dos neonatos, principalmente a cura do umbigo, para evitar infecções hematológicas que cheguem até as articulações.

Palavras-chave: Potro. Artrite. Onfalite. 